\title{
Organic carbon at a remote site of the western Mediterranean Basin: composition, sources and chemistry during the ChArMEx SOP2 field experiment
}

Vincent Michoud ${ }^{1,2,3}$, Jean Sciare ${ }^{4,5}$, Stéphane Sauvage ${ }^{1,2}$, Sébastien Dusanter ${ }^{1,2,6}$, Thierry Léonardis $^{1,2}$, Valérie Gros ${ }^{4}$, Cerise Kalogridis ${ }^{4}$, Nora Zannoni ${ }^{4}$, Anaïs Féron ${ }^{4}$, Jean-Eudes Petit $^{4,7, *}$, Vincent Crenn ${ }^{4}$, Dominique Baisnée ${ }^{4}$, Roland Sarda-Estève ${ }^{4}$, Nicolas Bonnaire ${ }^{4}$, Nicolas Marchand ${ }^{8}$, H. Langley DeWitt ${ }^{8}$, Jorge Pey ${ }^{8, *}$, Aurélie Colomb ${ }^{9}$, François Gheusi ${ }^{10}$, Sonke Szidat ${ }^{11}$, lasonas Stavroulas ${ }^{5}$, Agnès Borbon ${ }^{3, * * *}$, Nadine Locoge $e^{1,2}$

[1] Mines Douai, SAGE, F-59508, Douai, France

[2] Université de Lille, F-59655, Villeneuve d'Ascq, France

[3] LISA, UMR-CNRS 7583, Université Paris Est Créteil (UPEC), Université Paris Diderot (UPD), Institut Pierre Simon Laplace (IPSL), Créteil, France

[4] LSCE, IPSL, CEA et Université de Versailles, CNRS, Saint-Quentin, France

[5] The Cyprus Institute, Energy Environment Water Research Center, Nicosia, Cyprus

[6] School of Public and Environmental Affairs, Indiana University, Bloomington, IN, USA

[7] INERIS, 60550 Verneuil-en-Halatte, France

[8] Aix-Marseille Université, CNRS, LCE FRE 3416, 13331 Marseille, France

[9] LaMP, UMR-CNRS 6016, Clermont Université, Université Blaise Pascal, Aubière, France

[10] Laboratoire d'Aérologie, Université de Toulouse, CNRS, Toulouse, France

[11] Department of Chemistry and Biochemistry \& Oeschger Centre for Climate Change Research, University of Bern, Bern, Switzerland

*now at Air Lorraine, 20 rue Pierre Simon de Laplace, 57070 Metz, France

**now at the Geological Survey of Spain, 50006 Zaragoza (Spain)

***now at LaMP, UMR-CNRS 6016, Clermont Université, Université Blaise Pascal, Aubière, France 
Supplementary material 1: Lists of compounds contained in the different VOC standards used for PTR-ToFMS calibration

\begin{tabular}{|c|c|c|c|c|c|}
\hline $\begin{array}{l}\text { Species OVOC } \\
\text { cylinder } \\
\text { (Praxair) }\end{array}$ & $\begin{array}{l}\text { Mixing ratios } \\
\text { (ppm) }\end{array}$ & $\begin{array}{l}\text { Species HC cylinder } \\
\text { (Praxair) }\end{array}$ & $\begin{array}{l}\text { Mixing } \\
\text { ratios (ppm) }\end{array}$ & $\begin{array}{l}\text { Species Canister } \\
\text { (Restek) }\end{array}$ & $\begin{array}{l}\text { Mixing } \\
\text { ratios (ppm) }\end{array}$ \\
\hline Methanol & 2.15 & Acetonitrile & 0.63 & Méthanol & 1,05 \\
\hline Acetaldehyde & 1.43 & Acrylonitrile & 0.51 & Acetonitrile & 1,06 \\
\hline Acetone & 4.50 & Benzene & 0.96 & Acétaldéhyde & 1,04 \\
\hline $\begin{array}{l}\text { Methyl Ethyl } \\
\text { Ketone }\end{array}$ & 1.40 & Toluene & 0.91 & Acroléine & 0,91 \\
\hline 2-Methylfuran & 1.51 & EthylBenzene & 0.80 & Acétone & 0,99 \\
\hline Acrolein & 1.48 & $\begin{array}{l}1,2,4- \\
\text { TrimethylBenzene }\end{array}$ & 0.52 & Isoprène & 0,94 \\
\hline Methacrolein & 1.65 & Styrene & 0.71 & Crotonaldehyde & 0,92 \\
\hline $\begin{array}{l}\text { Methyl Vinyl } \\
\text { Ketone }\end{array}$ & 1.54 & Alpha-Pinene & 1.07 & 2-Butanone & 0,97 \\
\hline \multirow[t]{7}{*}{$\begin{array}{l}\text { 3-Methyl-2- } \\
\text { buten-1-ol }\end{array}$} & 0.60 & Methyl Sulfur & 1.14 & Benzène & 0,99 \\
\hline & & & & Toluène & 0,93 \\
\hline & & & & o-Xylène & 0,97 \\
\hline & & & & Chlorobenzène & 0,98 \\
\hline & & & & a-Pinène & 0,97 \\
\hline & & & & $\begin{array}{l}\text { 1,2- } \\
\text { Dichlorobenzène }\end{array}$ & 1,04 \\
\hline & & & & $\begin{array}{l}\text { 1, 2, 4- } \\
\text { Trichlorobenzène }\end{array}$ & 1,00 \\
\hline
\end{tabular}


Supplementary material 2: Lists of compounds contained in the different VOC standards used for GC calibration

\begin{tabular}{|c|c|}
\hline Species OVOC cylinder (Praxair) & $\begin{array}{l}\text { Mixing ratios } \\
\text { (ppm) }\end{array}$ \\
\hline Furane & 2.96 \\
\hline 2-méthyl furane & 2.98 \\
\hline Toluène & 2.98 \\
\hline Acétaldéhyde & 3.04 \\
\hline ETBE & 2.93 \\
\hline Tert-butylmethylether (MTBE) & 3.31 \\
\hline Tert-amylethylether (TAME) & 3.34 \\
\hline Méthacroleine & 2.96 \\
\hline Acétonitrile & 2.86 \\
\hline Butanal & 3 \\
\hline Acétone & 2.95 \\
\hline Pentanal & 3.43 \\
\hline MVK & 2.98 \\
\hline Acétate d'éthyle & 3 \\
\hline 2-Butanone & 3 \\
\hline Ethanol & 3.15 \\
\hline Hexanal & 3.36 \\
\hline Isopropanol & 3.08 \\
\hline 2-pentanone & 3.39 \\
\hline Heptanal & 3.39 \\
\hline 4methyl2pentanone(MIBK) & 3.39 \\
\hline Isobutanol & 3.15 \\
\hline Tert-butanol & 3.39 \\
\hline Acétate de butyle & 3 \\
\hline 2hexanone & 3.39 \\
\hline Butanol & 3.09 \\
\hline Benzaldéhyde & 2.96 \\
\hline 2heptanone & 3.39 \\
\hline 3-Methyl2buten-1-ol & 3.39 \\
\hline
\end{tabular}

Species HC cylinder (NPL)

\begin{tabular}{|c|}
\hline ethane \\
\hline ethylene \\
\hline propane \\
\hline propene \\
\hline isobutane \\
\hline acetylene \\
\hline
\end{tabular}

butane

T2-butene

1-butene

C2-butene

isopentane

pentane

1,3-butadiène

T2-pentene

1-pentene

isoprène

2methylpentane

hexane

benzene

isooctane

heptane

toluene

octane

ethylbenzene

$m+p$-xylene

o-xylene

135-trimethylbenzene

124-trimethylbenzene

123-trimethylbenzene

alpha-pinene

beta-pinene

limonene
Mixing ratios

(ppb)

\begin{tabular}{|c|}
\hline 1.85 \\
\hline 1.83 \\
\hline 1.82 \\
\hline 1.8 \\
\hline 1.83 \\
\hline 1.87 \\
\hline 1.78 \\
\hline 1.78 \\
\hline 1.75 \\
\hline 1.75 \\
\hline 1.78 \\
\hline 1.8 \\
\hline 1.8 \\
\hline 1.72 \\
\hline 1.75 \\
\hline 1.78 \\
\hline 1.78 \\
\hline 1.78 \\
\hline 1.79 \\
\hline 1.79 \\
\hline 1.76 \\
\hline 1.77 \\
\hline 1.77 \\
\hline 2.12 \\
\hline 4.2 \\
\hline 2.19 \\
\hline 2.18 \\
\hline 2.27 \\
\hline 2.12 \\
\hline 2.03 \\
\hline 1.95 \\
\hline 2.01 \\
\hline \\
\hline
\end{tabular}


Supplementary material 3: Comparison of alkane ratios obtained during the ChArMEx SOP2 field campaign in Cape Corsica to ratios obtained for receptor sites of different typologies.

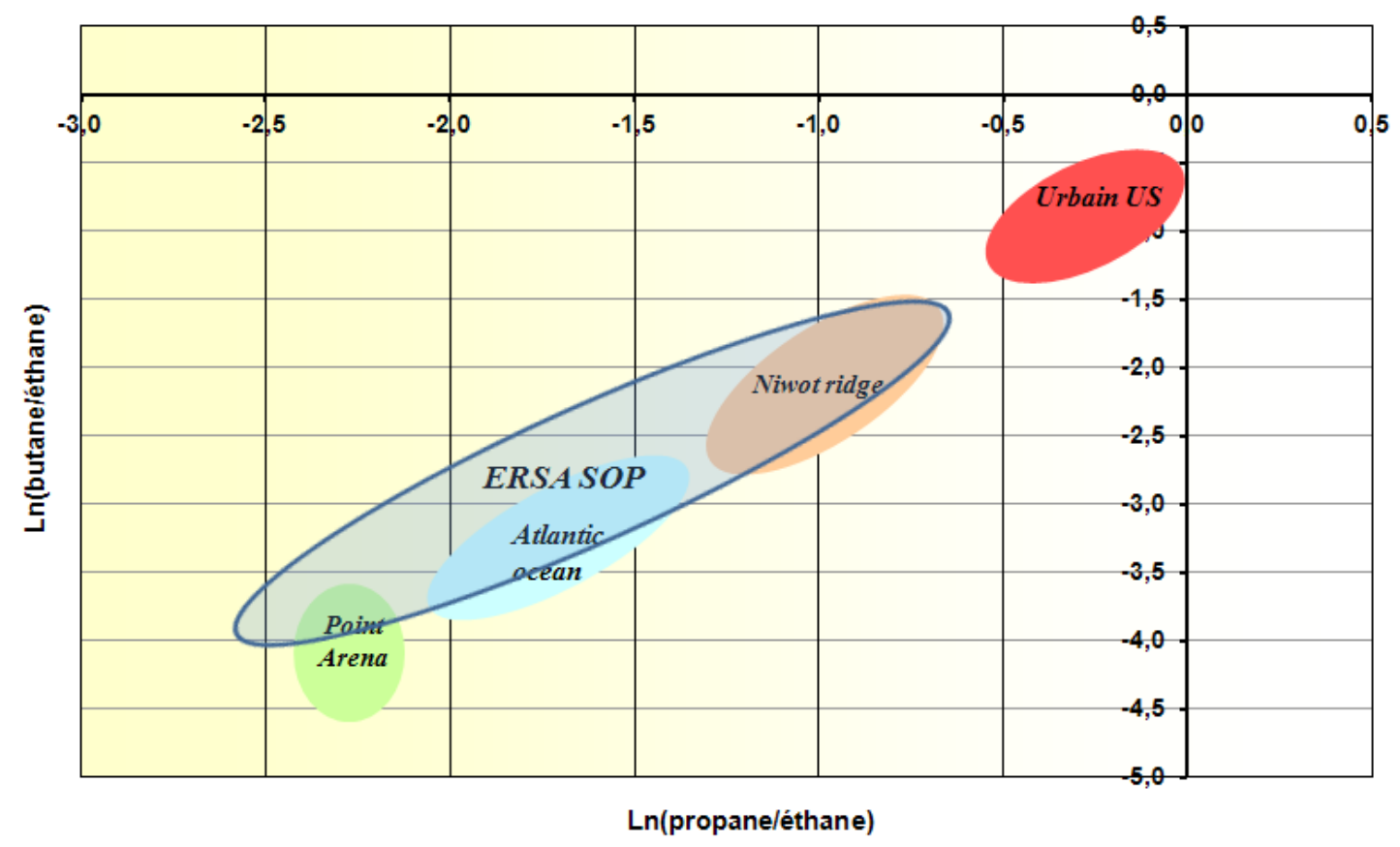

Figure S3: Evolution of $\operatorname{Ln}$ (butane/ethane) as a function of $\operatorname{Ln}$ (propane/ethane) represented as graphic areas for different receptor site typologies (Parrish et al., 1992) and for the ChArMEx SOP2 field campaign in Cape Corsica (blue ellipse). The sites have been chosen because they are characteristic of environments close to sources up to very remote areas (Urban, Niwot Ridge: remote continental site, Atlantic Ocean: remote oceanic site, Point Arena: highly remote site). 
Supplementary material 4: Results of mapping of bootstrap factors to base run factors from the VOC PMF analysis

\begin{tabular}{|l|r|r|r|r|r|r|r|}
\hline & Base Factor 1 & Base Factor 2 & Base Factor 3 & Base Factor 4 & Base Factor 5 & Base Factor 6 Unmapped \\
\hline boot Factor 1 & 100 & 0 & 0 & 0 & 0 & 0 & 0 \\
\hline boot Factor 2 & 0 & 86 & 0 & 3 & 0 & 0 & 11 \\
\hline boot Factor 3 & 0 & 0 & 100 & 0 & 0 & 0 & 0 \\
\hline boot Factor 4 & 0 & 4 & 0 & 89 & 1 & 0 & 6 \\
\hline boot Factor 5 & 0 & 0 & 0 & 0 & 88 & 0 & 12 \\
\hline boot Factor 6 & 0 & 0 & 0 & 0 & 0 & 100 & 0 \\
\hline
\end{tabular}




\section{Supplementary material 5: Repartition of measured VOCs}

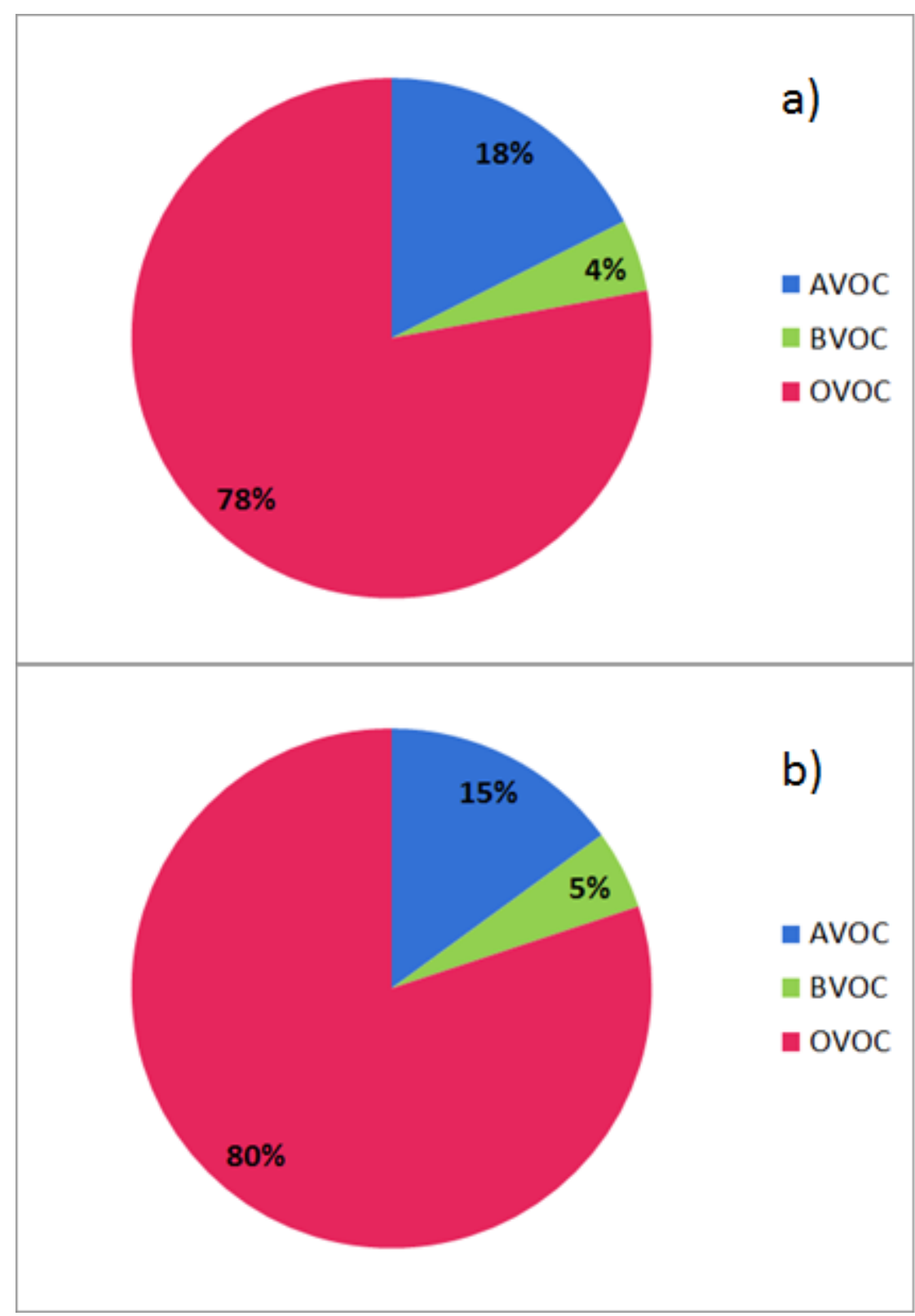

Figure S5: Distribution of the VOC families (AVOC: Anthropogenic non methane hydrocarbons, BVOC: Biogenic hydrocarbons, OVOC: Oxygenated VOCs including primary and secondary VOCs from anthropogenic and biogenic origins) at cape Corsica during the ChArMEx SOP2 field campaign, calculated from the full VOC database not including DNPH cartridges measurements (Top panel a) and from the database used for PMF analysis (Bottom panel b). 
Supplementary material 6: Distribution of PMF factor contributions to the sum of species included in the database used for PMF analysis

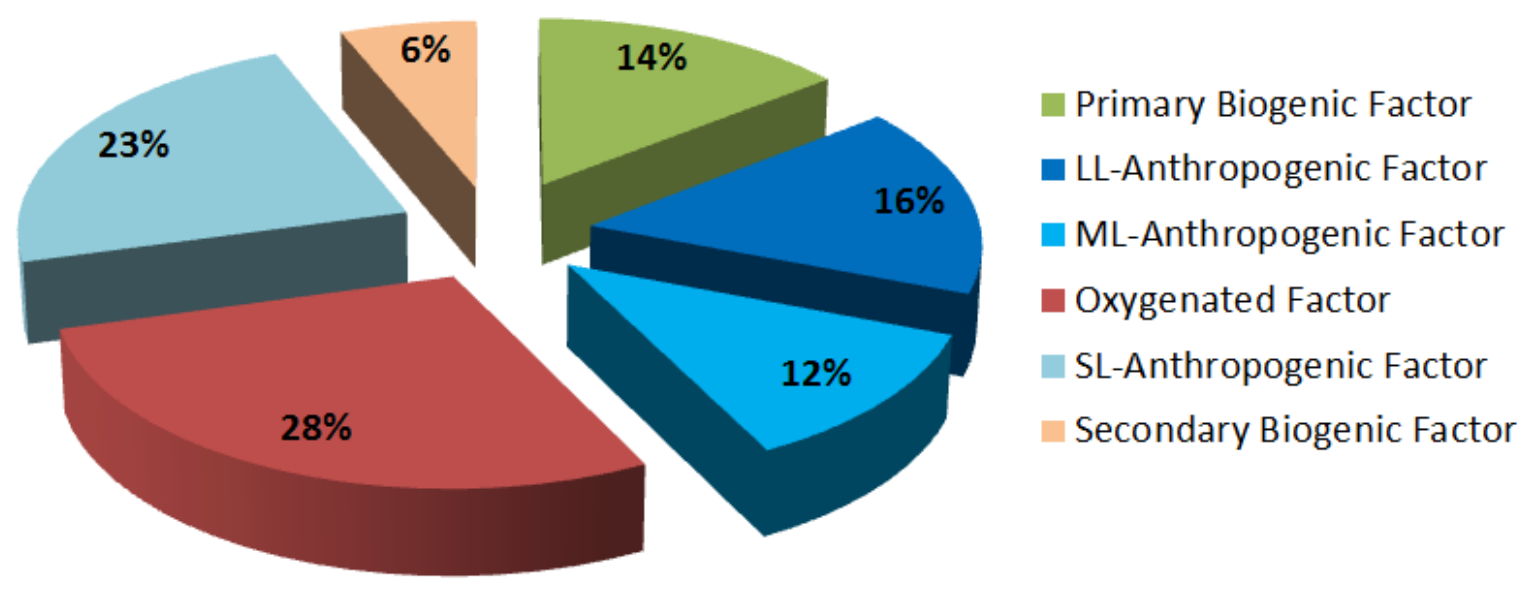

Figure S6: The relative contributions of the different PMF factors to the sum of species used as inputs. 


\section{Supplementary material 7: Scatter plots of various parameters with contribution of PMF factors}
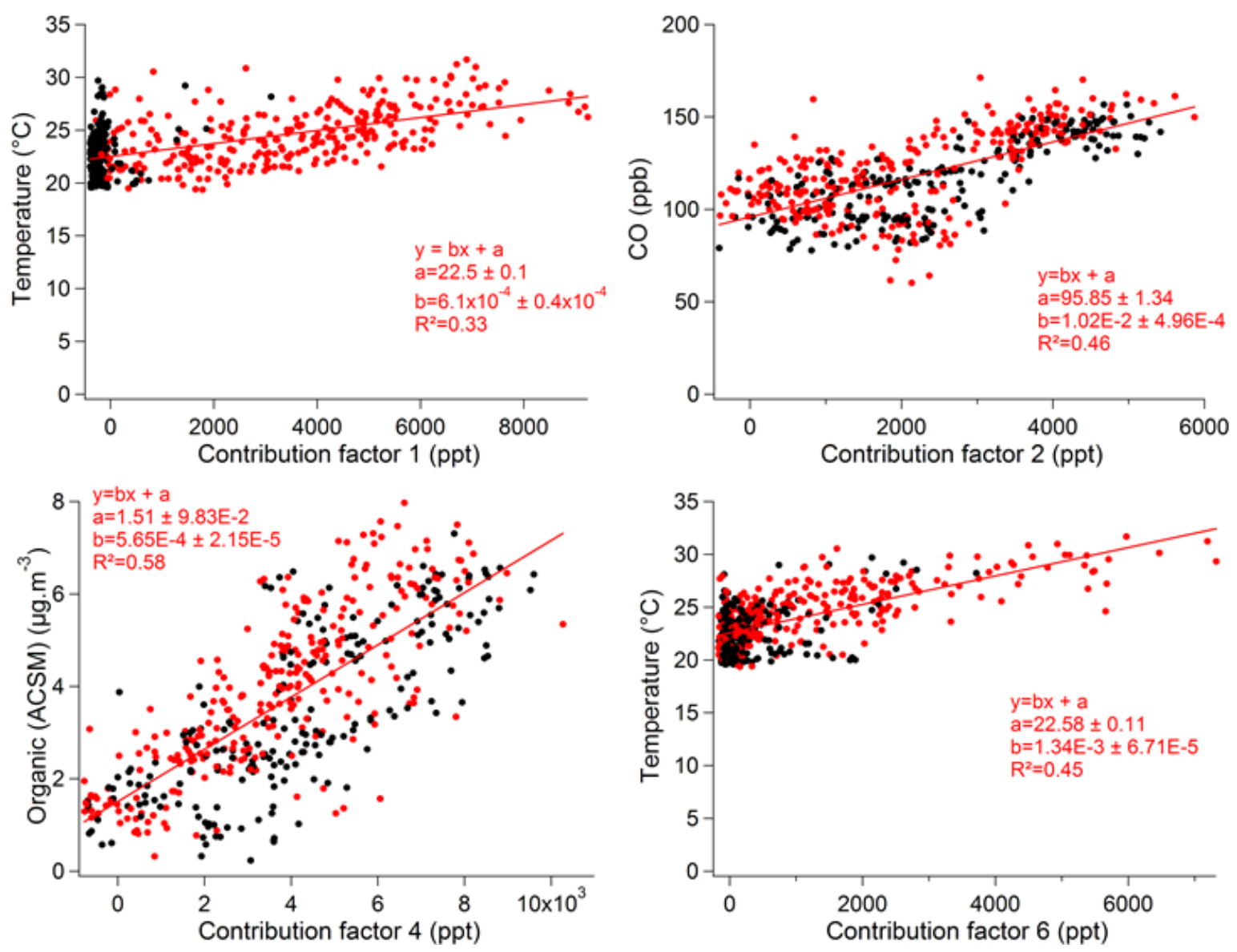

Figure S7: Scatter plots of temperature vs. contribution of factor 1 (top left), mixing ratios of $\mathrm{CO}$ vs. contribution of factor 2 (top right), organic fraction of aerosols vs. contribution of factor 4 (bottom left), and temperature vs. contribution of factor 6 (bottom right). Every scatter plots have been color-coded according to the period of the day (daytime: 07:00-20:00 local time in red; nighttime: 21:00-06:00 local time in black). 


\section{Supplementary material 8: Diurnal Profile of Factor contributions}

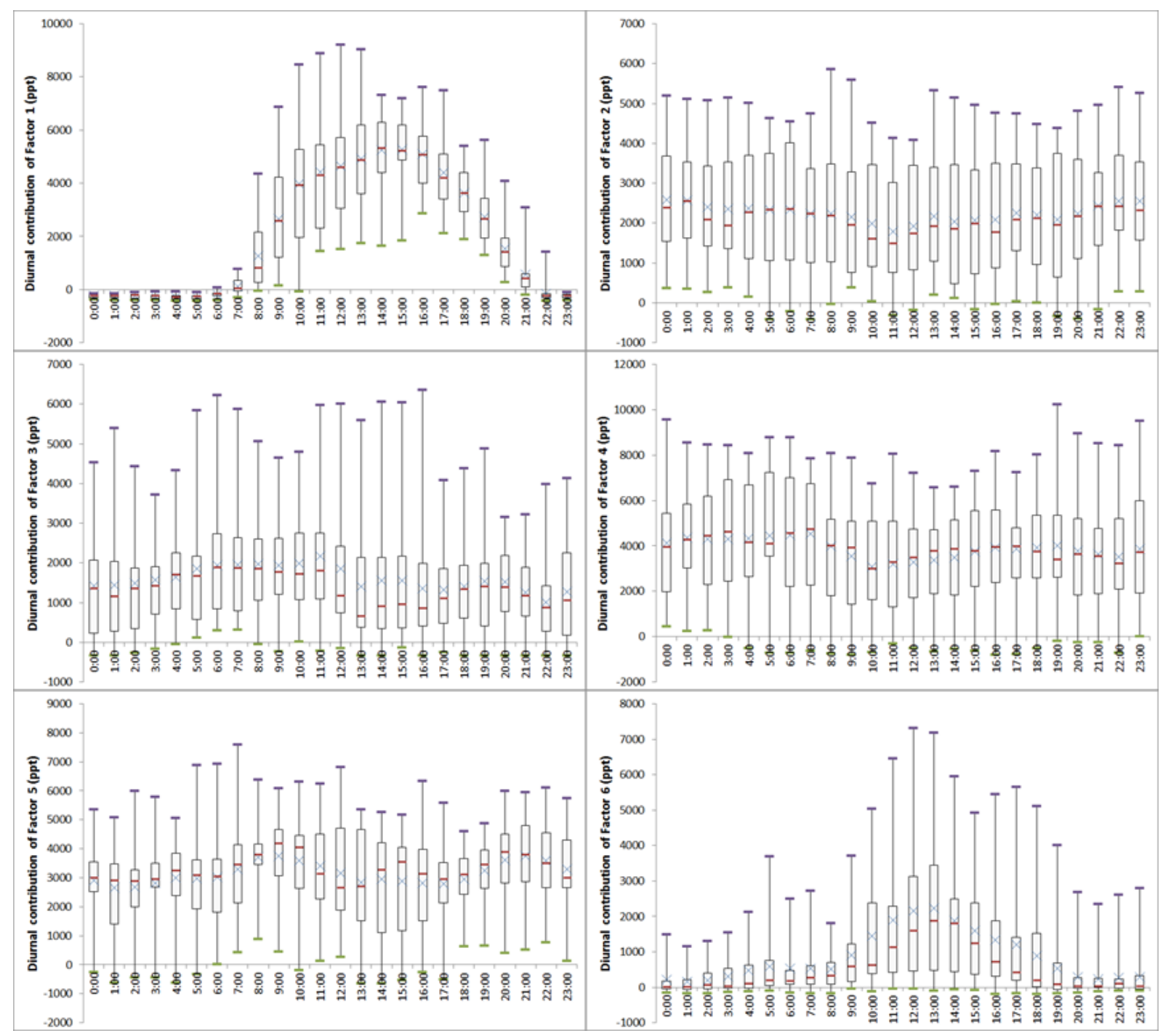

Figure S8: Diurnal profiles (Boxplots) of contributions of PMF factors during the ChArMEx SOP2 field campaign. Purple bars represent the maxima of the campaign, green bars the minima of the campaign, red bars the medians of the campaign, blue crosses the averages of the campaign, and the side of the boxes: the first (bottom) and the third (top) quartiles of the campaign. 
Supplementary material 9: Diurnal profiles of OOA

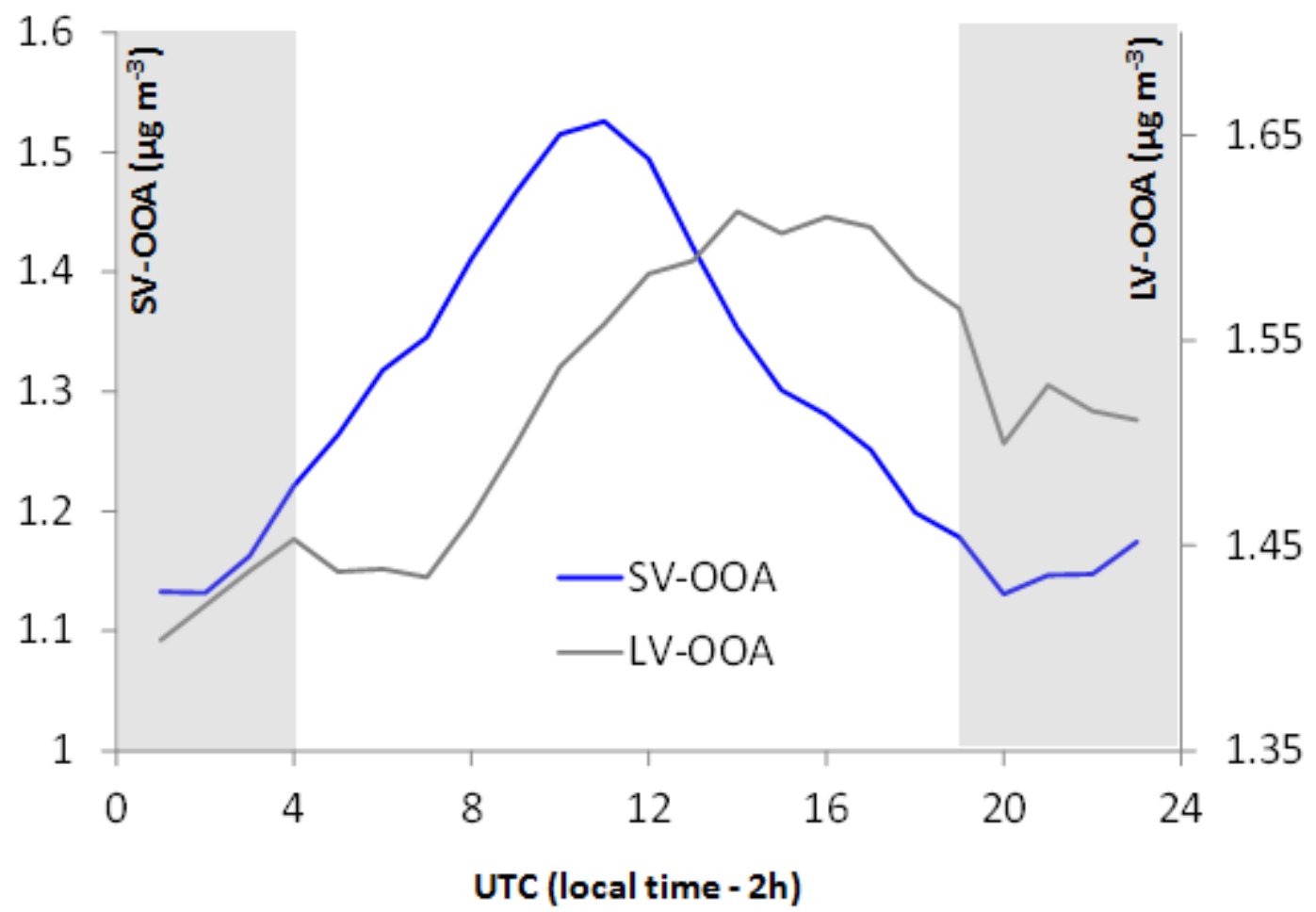

Figure S9: Diurnal variability of SV-OOA (blue line) and LV-OOA (grey line) at Cape Corsica. Grey zones correspond to nighttime. 


\section{References}

Parrish, D. D., Hahn, C. J., Williams, E. J., Norton, R. B., and Fehsenfeld, F. C.: Indications of photochemical histories of pacific air masses from measurements of atmospheric trace species at Point Arena, California, J. Geophys. Res.-Atmos., 97, 15883- 15901, 1992. 